\title{
Magnetic Resonance Imaging of Adipose Tissue in Metabolic Dysfunction
}

\section{MR-Bildgebung von Fettgewebe bei Stoffwechselstörungen}

Authors

Daniela Franz ${ }^{1}$, Jan Syväri' ${ }^{1}$ Dominik Weidlich ${ }^{1}$, Thomas Baum² ${ }^{2}$ Ernst J Rummeny¹, Dimitrios C. Karampinos ${ }^{1}$

\section{Affiliations}

1 Institute for Diagnostic and Interventional Radiology, Technische Universität München, Fakultät für Medizin, Munich, Germany

2 Institute for Diagnostic and Interventional Neuroradiology, Technische Universität München, Fakultät für Medizin, Munich, Germany

Key words

MR imaging, MR spectroscopy, adipose tissue, brown fat, metabolic disorders

received 02.11 .2017

accepted 07.04.2018

Bibliography

DOI https://doi.org/10.1055/a-0612-8006

Published online: 6.6.2018

Fortschr Röntgenstr 2018; 190: 1121-1130

(c) Georg Thieme Verlag KG, Stuttgart · New York

ISSN 1438-9029

Correspondence

Daniela Franz

Institut für diagnostische und interventionelle Radiologie,

Klinikum rechts der Isar, Ismaniger Str. 22, 81675 München,

Germany

Tel.: $++49 / 89 / 41400$

Fax: ++ 49/89/41407709

daniela.franz@tum.de

\section{ZUSAMMENFASSUNG}

Hintergrund Fettgewebe rückt zunehmend in den Fokus der Medizin. Es spielt eine zentrale Rolle bei der Speicherung und Freisetzung von Energie im gesamten menschlichen Körper und hat aufgrund seiner endokrinologischen Funktion in letzter Zeit das Interesse der Wissenschaft geweckt. Die Magnetresonanztomografie (MRT) ist eine etablierte Methode zur quantitativen direkten Beurteilung der Fettgewebsverteilung und wird zunehmend als Methode der Wahl für die metabolische Phänotypisierung eingesetzt. Der Zweck dieser Übersichtsarbeit ist die Identifizierung und Darlegung der derzeit verfügbaren Literatur über die MRT von Fettgewebe bei Stoffwechselstörungen.

Methode Eine PubMed (http://www.ncbi.nlm.nih.gov/ pubmed) Schlagwortsuche bis August 2017 ohne Einschrän- kung hinsichtlich des Startdatums wurde durchgeführt und Referenzlisten relevanter Artikel wurden durchsucht.

Ergebnisse und Schlussfolgerung Die MRT bietet hervorragende Möglichkeiten zur Beurteilung der Fettgewebsverteilung und zur weiteren Charakterisierung des Gewebes. Standard-sowie neu entwickelte MRT-Techniken erlauben eine Risikostratifizierung hinsichtlich der Entwicklung von Stoffwechselstörungen und ermöglichen ein weiteres Monitoring ohne den Einsatz von ionisierender Strahlung oder Kontrastmittel.

\section{Kernaussagen}

- Verschiedene Typen von Fettgewebe spielen bei Stoffwechselstörungen eine entscheidende Rolle.

- Die Magnetresonanztomografie bietet hervorragende Möglichkeiten zur nicht-invasiven Evaluation von Fettgewebe hinsichtlich dessen Verteilung, Zusammensetzung und Stoffwechselaktivität.

- Sowohl MRT-Standardtechniken als auch neu entwickelte Techniken erlauben die Risikostratifizierung bzgl. Stoffwechselstörungen und ermöglichen deren Monitoring ohne den Gebrauch von ionisierender Strahlung oder Kontrastmittel.

\section{ABSTRACT}

Background Adipose tissue has become an increasingly important tissue target in medicine. It plays a central role in the storage and release of energy throughout the human body and has recently gained interest for its endocrinologic function. Magnetic resonance imaging (MRI) is an established method for quantitative direct evaluation of adipose tissue distribution, and is used increasingly as the modality of choice for metabolic phenotyping. The purpose of this review was the identification and presentation of the currently available literature on MRI of adipose tissue in metabolic dysfunction. Method A PubMed (http://www.ncbi.nlm.nih.gov/pubmed) keyword search up to August 2017 without starting date limitation was performed and reference lists of relevant articles were searched.

Results and Conclusion MRI provides excellent tools for the evaluation of adipose tissue distribution and further characterization of the tissue. Standard as well as newly developed MRI techniques allow a risk stratification for the development of metabolic dysfunction and enable monitoring without the use of ionizing radiation or contrast material. 
Key points

- Different types of adipose tissue play a crucial role in various types of metabolic dysfunction.

- Magnetic resonance imaging (MRI) is an excellent tool for noninvasive adipose tissue evaluation with respect to distribution, composition and metabolic activity.

- Both standard and newly developed MRI techniques can be used for risk stratification for the development of meta- bolic dysfunction and allow monitoring without the use of ionizing radiation or contrast material.

\section{Citation Format}

- Franz D, Syväri J, Weidlich D et al. Magnetic Resonance Imaging of Adipose Tissue in Metabolic Dysfunction. Fortschr Röntgenstr 2018; 190: 1121-1130

\section{Introduction}

Over the last decades, adipose tissue has become an increasingly important tissue both in research and in clinical medicine. It is well known that adipocytes play a crucial role in the storage and release of energy throughout the human body. Adipose tissue as an active endocrine organ has only recently gained significant interest in the scientific community. Studies during the last years have discovered adipose tissue to express and secrete endocrine factors (e. g. leptin, adiponectin, complement components, plasminogen activator inhibitor- 1 and proteins of the renin-angiotensin system) in response to specific stimuli. Through a system of afferent and efferent signals, adipose tissue is involved in coordinating numerous biological processes including energy metabolism, neuroendocrine function and immune function [1].

Diseases altering adipose tissue mass and function are linked to various metabolic disturbances and cardiovascular risk factors. For example, obesity with its abundance of adipose tissue is a chronic disease representing a leading cause for multi-morbidity and mortality worldwide, while cancer cachexia as the opposite is the cause of death in up to $30 \%$ of cancer-related deaths [2]. There is therefore an urgent need for successful prevention and treatment options for diseases related to metabolic dysfunction. Improved metabolic phenotyping and risk stratification based on adipose tissue biomarkers can play an important role in the clinical management of patients with metabolic dysfunction.

Indirect quantification methods such as dual energy X-ray absorptiometry (DEXA) do not necessarily provide accurate information about the exact distribution of the adipose tissue (e. g. visceral vs. subcutaneous depots) [3]. However, knowledge about the exact three-dimensional adipose tissue distribution is critical for risk stratification with regard to disease development [4]. Magnetic resonance imaging (MRI) has been on the rise for direct imaging of fat depots, after CT imaging, necessarily involving ionizing radiation, has been used in earlier studies. Thanks to its non-invasive characteristics, MRI enables longitudinal monitoring of larger human populations. After numerous studies applied MRI successfully for quantitative direct evaluation of adipose tissue distribution, MRI is increasingly considered as the gold standard for metabolic phenotyping [5].

Additionally, magnetic resonance spectroscopy (MRS) provides the opportunity to non-invasively explore specific MR signatures based on the tissue's endogenous biochemical and histological characteristics. Furthermore, new developments in MRI techniques provide researchers with further tools to characterize adi- pose tissue depots, exploiting the multi-contrast capabilities of MRI.

The purpose of this review was the identification and presentation of the currently available literature on MRI of adipose tissue in metabolic dysfunction.

\section{Literature Search}

PubMed (http://www.ncbi.nlm.nih.gov/pubmed) was used for keyword search up to August 2017 in order to identify relevant studies for this review. No starting date limitation was used so that all the relevant literature available in PubMed would be covered. Search terms used included "MRI"; "magnetic resonance imaging" and "1H-based magnetic resonance spectroscopy" in combination with "adipose tissue"; "fat”; "brown fat", "brown adipose tissue”, "cachexia”; “anorexia”; “diabetes”; “obesity”, "metabolic dysfunction" and "metabolic syndrome"; The search was not restricted to studies in humans. Reference lists of relevant articles were also searched.

\section{Types of adipose tissue}

There are several ways to classify adipose tissue. First, it should be noted that "fat" and "adipose tissue" are terms used interchangeably in the daily routine. However, "fat" and "adipose tissue" do not refer to the same body component [6]. Adipose tissue is a special type of connective tissue, which is composed mainly of adipocytes and usually contains $>80 \%$ lipids. Water, proteins and minerals are other components of adipose tissue. Fat, on the other hand, is the lipid itself, usually in the form of triglycerides. Fat can be found mainly in adipose tissue, but- especially in pathologic states- also in other organs such as the liver and the muscle as the so called ectopic fat [7].

Adipose tissue, for its part, can be classified based on its histological and functional properties as white, brown or beige (brownin-white) adipose tissue. The latter mentioned beige adipose tissue will not be further addressed in this article, as methods to characterize it with imaging are still in early stages of development [8, 9]. MRI is a way to differentiate between white and brown adipose tissue (WAT and BAT) based on their different characteristics from a histological (e. g. based on their water content) and also functional (e. g. based on their blood perfusion) point of view, as described in detail later on in the section "MRI characteristics of white and 
brown adipose tissue". White adipose tissue can be further classified based on its location in the human body [6].

\section{MRI methods}

MRI has been used in various studies for evaluation of adipose tissue distribution throughout the body and assessment of adipose tissue characteristics [10-14]. MRI techniques relying on the difference between the relaxation and chemical shift properties of fat compared to water have been primarily used to segment adipose tissue depots and measure fat concentration.

$\mathrm{T}_{1}$-weighted imaging is able to discriminate proton signals from water and fat based on their different $T_{1}$ relaxation times and the hyperintense signal of WAT in contrast to non-adipose tissues [15]. $T_{2}$-weighted imaging also relies on $T_{2}$ relaxation times with adipose tissue appearing hyperintense on $\mathrm{T}_{2}$-weighted images. $T_{1}$-weighted techniques have been predominantly used for adipose tissue segmentation by applying signal intensity thresholding algorithms [16, 17]. Besides the strong fat tissue contrast and their good spatial resolution, the widespread availability of $\mathrm{T}_{1}$-weighted imaging is a big advantage of the method. Limitations of the method are the sensitivity to $B_{1}$ inhomogeneities and difficulties on setting the appropriate threshold in the presence of partial volume effects.

MRS provides an approach to noninvasively characterize adipose tissue based on the chemical shift properties of its constituents. ${ }^{1} \mathrm{H}$-MRS and ${ }^{13} \mathrm{C}-\mathrm{MRS}$ are two exemplary methods to assess the degree of unsaturation of adipose tissue and have been primarily applied by using single-voxel MRS techniques [18-20]. MRS is the only available non-invasive technique to analyze the triglyceride composition of a tissue (saturated, monounsaturated, polyunsaturated). An exemplary application for fat composition assessment with MRS is described in a murine disease model of an inherited defect in $\beta$-oxidation found in humans [21].

Chemical shift encoding-based water-fat MRI allows the acquisition of co-registered water- and fat-separated images and fat, i. e. lipid quantification with high spatial resolution. The simultaneous acquisition of water- and fat-separated images enables the segmentation of adipose tissue depots using k-means clustering approaches [16]. In addition, the "proton density fat fraction" (PDFF) has been emerging as the most reliable MR-based biomarker for fat quantification purposes. The MR-based PDFF is defined as the ratio of density of mobile protons from fat (triglycerides) and the total density of protons from mobile triglycerides and mobile water [22]. With the use of a prior known fat spectrum to model the spectral complexity of fat, a low flip angle to alleviate bias from $T_{1}$ relaxation, and acquisition of multiple echoes for $T_{2}{ }^{*}$ correction, PDFF reflects the proton density tissue content in fat. It can be acquired by using for example a six-echo multi-echo gradient echo sequence. PDFF maps are then generated using typically a complex-based water-fat separation algorithm. On these maps, regions of interest can be defined and their PDFF is displayed in percent. PDFF has been validated in the liver against reference histological methods [23-25]. In adipose tissues, PDFF shows a high variability, ranging from values as low as $50-65 \%$ in BAT up to $90-100 \%$ in WAT $[13,26,27]$.

\section{MRI characteristics of white and brown adipose tissue}

\section{White adipose tissue}

White adipose tissue (WAT) is a storage for fat in the form of triglycerides and has several endocrine functions for inter-organ cross-talk [28]. Histologically, white adipose tissue is characterized by large adipocytes containing a big intracellular lipid droplet, a small nucleus and only few cytoplasm. Blood supply of WAT is sparse. WAT can be found in subcutaneous and visceral locations. It can be further classified based on its body location [6]. Subcutaneous adipose tissue (SAT) is defined as the layer between the dermis and the aponeuroses and fasciae of the muscles, including mammary adipose tissue. Abdominal SAT can be further divided into deep and superficial subcutaneous adipose tissue. The two subdivisions of SAT have been associated differently with cardiometabolic parameters [29]. Visceral adipose tissue (VAT) is defined as fat depot within the abdomen, pelvis and within the chest [6].

Various studies applied MRI in order to segment and quantify the amount of WAT $[16,17,30]$. MRI and MRS are widely used techniques to accurately quantify and characterize WAT. $\mathrm{T}_{1}$ weighted and water-fat imaging methods enable easier segmentation of WAT and subsequently volume quantification. Such quantitative measurements allow longitudinal monitoring of the adipose tissue depots in observational or lifestyle intervention studies. $\mathrm{T} 1$ relaxation times might be also of use for the non-invasive assessment of WAT, as a pilot study suggested by showing a difference in $\mathrm{T} 1$ relaxation times between severely obese and lean subjects [31].

On fat quantification, WAT depots expose a high fat fraction or PDFF, which is reflective of the high amount of lipids within the tissue. In WAT, the PDFF usually ranges around $90 \%$ [13, 26, $32-34]$ ( $\vee$ Fig. 1). In weight loss, however, the fatty component of adipose tissue can reduce, as it was shown with the use of single-voxel ${ }^{1} \mathrm{H}$ MRS by Sadananthan et al. [35].

MRS is able to give information about the fatty acid composition in WAT. Hamilton showed that the triglyceride composition could be measured reliably using ${ }^{1} \mathrm{H}$-MRS at $3 \mathrm{~T}$, and that different triglyceride compositions could be detected in different WAT depots (visceral, superficial subcutaneous and deep subcutaneous), suggesting that the particular WAT depots have distinct metabolic activities [36] Another study reporting on intra- and interindividual differences of fatty acid composition in human adipose tissue is a recent work by Machann et al., showing distinct patterns of fatty acid composition in six different locations in the body [37].

\section{Brown adipose tissue}

Brown adipose tissue (BAT) is a specialized adipose tissue oxidizing glucose and fatty acids via non-shivering thermogenesis for maintenance of body temperature [38-40]. In humans, BAT can be identified in supraclavicular and cervical as well as paravertebral depots. More anatomic sites where BAT can be found (e. g. perirenal, mediastinal) have been described in postmortem studies 


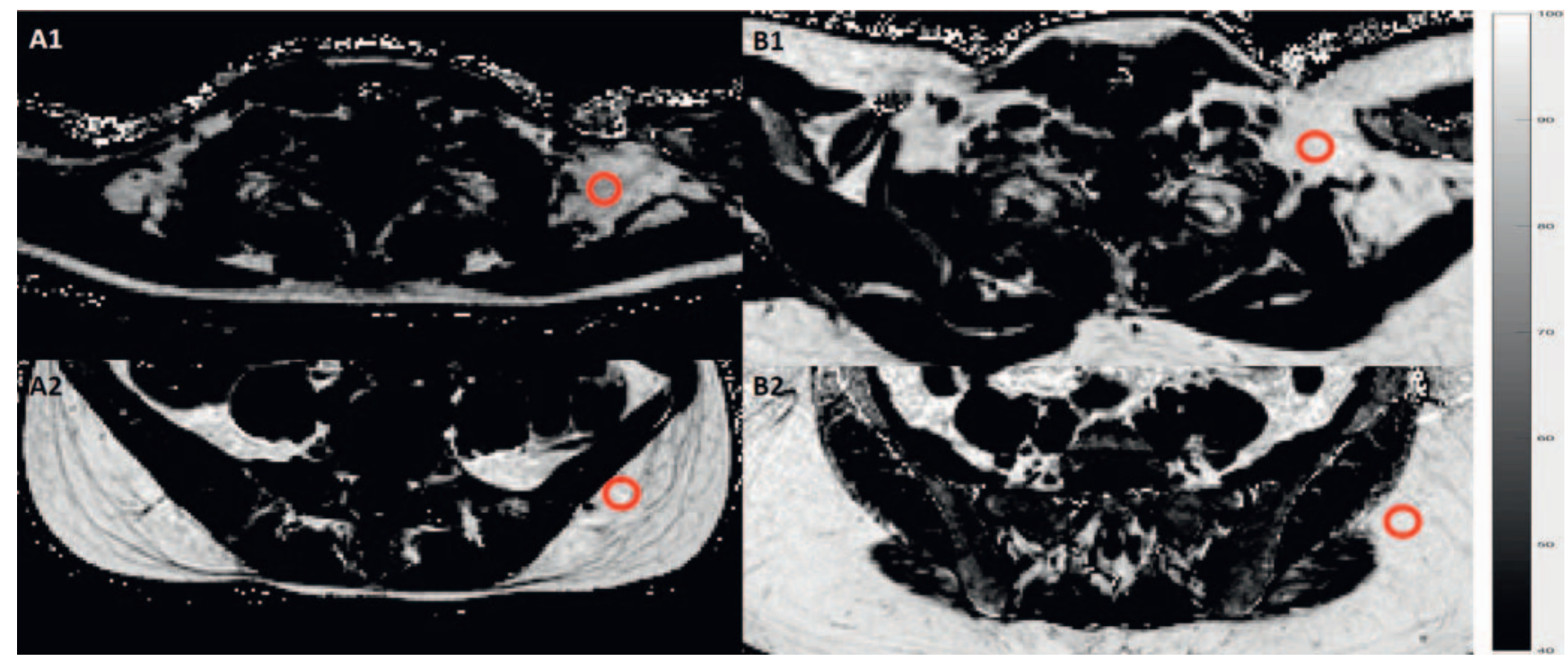

- Fig. 1 Comparison of supraclavicular (first row) and gluteal (second row) fat depots in a low BMI female subject (first column A, BMI: $17.5 \mathrm{~kg} / \mathrm{m}^{2}$ ) and a high BMI female subject (second column B, BMI: $38 \mathrm{~kg} / \mathrm{m}^{2}$ ). Regions of interest are marked with red ellipses. The high BMI subject has higher supraclavicular PDFF (91\%) and higher gluteal PDFF (93\%) than the low BMI subject (77\% supraclavicular and $88 \%$ gluteal). The low PDFF in supraclavicular adipose tissue in the low BMI subject $\mathbf{A}$ points to the presence of brown adipose tissue, which has a lower PDFF than white adipose tissue. PDFF: proton density fat fraction, BMI: body mass index.

- Abb. 1 Vergleich der supraklavikulären (erste Reihe) und glutealen (zweite Reihe) Fettkompartimente bei einer weiblichen Probandin mit niedrigem BMI (erste Spalte A, BMI: 17,5 kg/m²) und einer Probandin mit hohem BMI (zweite Spalte B, BMI: $38 \mathrm{~kg} / \mathrm{m}^{2}$ ). Die zu untersuchenden Regionen sind mit roten Ellipsen markiert. Die Probandin mit hohem BMI weist eine höhere supraklavikuläre PDFF (91\%) und eine höhere gluteale PDFF (93\%) auf als die Probandin mit niedrigem BMI (77\% supraklavikulär und $88 \%$ gluteal). Die niedrige PDFF im supraklavikulären Fettgewebe der Probandin mit niedrigem BMI A weist auf das Vorhandensein von braunem Fettgewebe hin, welches eine niedrigere PDFF aufweist als weißes Fettgewebe. PDFF: Proton Density Fat Fraction, BMI: Body Mass Index.

[41]. On a cellular base, BAT is an extensively vascularized adipose tissue with large amounts of iron-containing mitochondria, expressing uncoupling protein 1 (UCP-1), a protein uncoupling oxidative phosphorylation from ATP production, thereby releasing energy as heat $[38,39]$. It contains a high quantity of intracellular water while lipid is present in the form of large amounts of small lipid droplets. BAT is metabolically active mainly throughout early childhood, but active BAT can also be detected in adults [41, 42]. BAT recruitment was used as a therapeutic approach for obesity, elevated triglyceride concentrations, and type 2 diabetes in rodents in several studies $[13,43]$. Furthermore, it has been shown that the amount of BAT is inversely correlated with body-mass index (BMI) in humans, suggesting a potential role of BAT in adult human metabolism [38]. Therefore, the identification of BAT and its further characterization has become of great interest in the field of metabolic research. Until recently, the gold standard of the detection of metabolically active BAT was $18 \mathrm{~F}$-fluorodeoxyglucose positron emission tomography (PET) with computed tomography (CT). However, one major limitation of PET/CT is the clinically significant doses of ionizing radiation. Furthermore, PET/CT depends on the metabolic activity of BAT, thus BAT needs to be in an active state during the examination, limiting the validity of this modality in measuring BAT volume at the resting state [13].

With the use of MRI, BAT can be distinguished from WAT based on its higher water content. This results in a lower fat fraction in BAT compared to WAT. Thus, the most commonly used MRI methods to study BAT in humans are chemical shift-encoding based fat quantification techniques [44, 45]. After consideration of the aforementioned confounding factors, chemical shift encodingbased fat quantification techniques can display the PDFF [22]. Several studies have shown BAT to have a significantly lower PDFF compared to WAT, reflecting the higher water content and lower fat content of BAT compared to WAT [13] ( $\vee$ Fig. 1).

With MRS being capable of depicting differences in fat fraction, $T_{1}$ relaxation rate of the water component, and the degree of lipid saturation in BAT, it provides the opportunity to depict the biochemical profile of the adipose tissue ( $\vee$ Fig. 2 ). Hamilton et al. used MRS on a whole-body 3T-scanner on excised tissue samples of murine BAT and WAT [46], showing a lower fat fraction, lower proportion of unsaturated triglycerides, and a markedly lower $\mathrm{T}_{1}$ relaxation rate of the water component in BAT compared to WAT. However, with BAT being located in the supraclavicular region in humans, the use of MRS is limited as the region is affected by motion, large vessels and magnetic field inhomogeneities due to the neighboring lungs and strongly alternating diameters (thorax/ neck).

Newer MRI methods are capable of illustrating not only the chemical structure of BAT, but also its functional activation status, which is of great interest in BAT research. Until recently, BAT activation could only be detected with the use of 18F-FDG PET, which implicates radiation exposure. MRI offers techniques to depict BAT activation via its metabolites. Lau et al. used hyperpolarized ${ }^{13} \mathrm{C}$ imaging to noninvasively identify activated depots of BAT in an in vivo rat model. Regions of pharmacologically activated BAT 


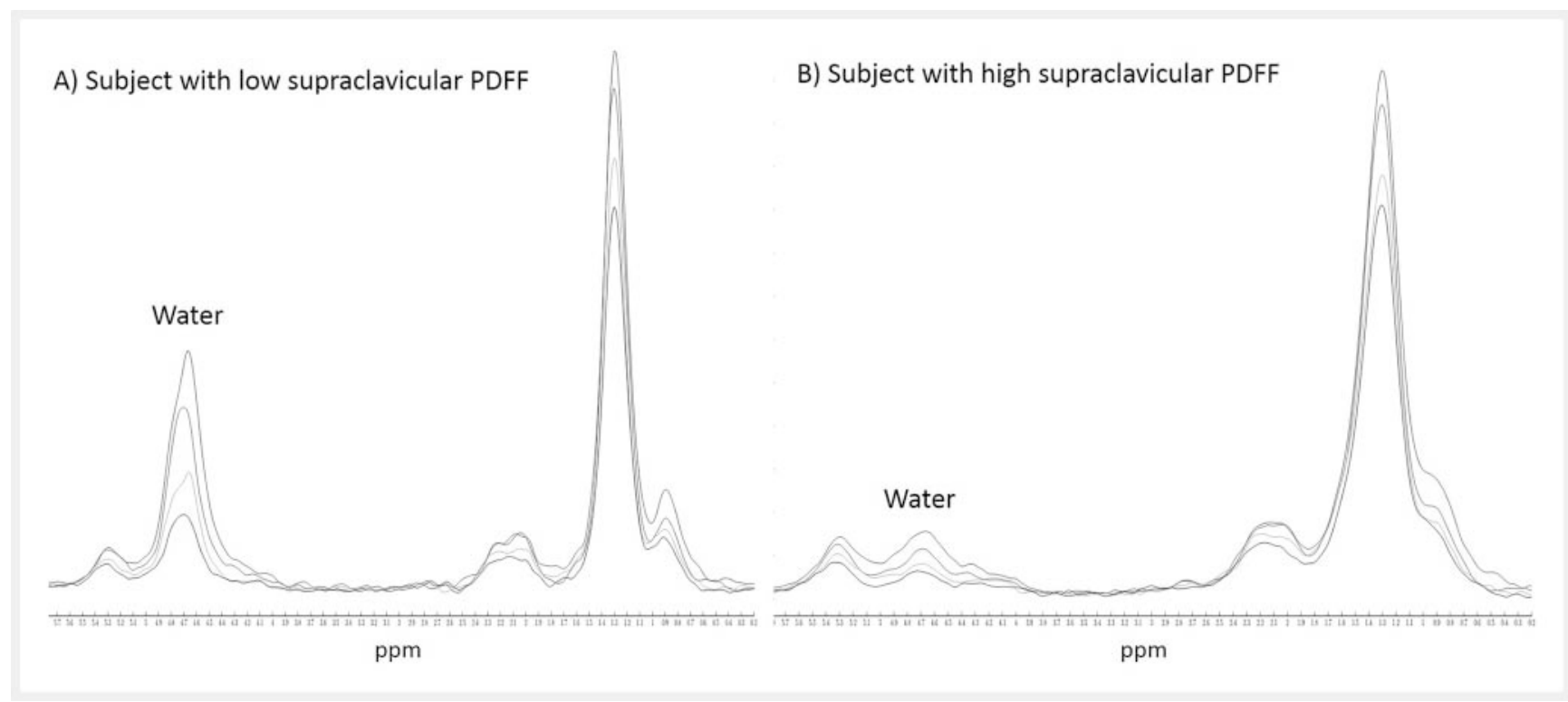

- Fig. 2 Multi-TE single-voxel STEAM MR spectroscopy at 3 T (TR: 3000 ms, TE: 12-20-28-36 ms) in two female subjects. Supraclavicular spectra of subject with low supraclavicular PDFF A and supraclavicular spectra of subject with high supraclavicular PDFF B. Note the large water peak in the subject with low PDFF compared to the subject with high PDFF (suggesting the presence of brown adipose tissue in subject $\mathbf{A}$ ) and the faster T2 decay of the water peak compared to the fat peaks. TE: echo time, TR: repetition time.

- Abb. 2 Multi-TE single-voxel STEAM MR Spektroskopie bei 3 T (TR: 3000 ms, TE: 12-20-28-36 ms) bei zwei weiblichen Probandinnen. Spektren des supraklavikulären Fettgewebes bei einer Probandin mit niedriger PDFF A und einer Probandin mit hoher PDFF B. Man beachte den höheren Wasser-Peak im supraklavikulären Fettgewebe bei der Probandin mit niedriger PDFF im Vergleich zur Probandin mit hoher PDFF (als Hinweis auf das Vorliegen von braunem Fett bei Probandin A) sowie den schnelleren T2-Zerfall des Wasser-Peaks verglichen mit den Fett-Peaks. TE: Echozeit, TR: Repetitionszeit.

could be detected by an increased conversion of pre-polarized $(1-13 C)$ pyruvate into its downstream products $13 \mathrm{C}$ bicarbonate and $(1-13 \mathrm{C})$ lactate [47]. Grimpo et al. used $1 \mathrm{H}$ MRS to monitor the metabolic dynamics in murine BAT and detected a significant loss of free fatty acids from BAT after pharmacological stimulation [48]. Quantification of blood flow and perfusion of BAT is another method to collect information about BAT activation. Blood flow and perfusion can be illustrated with the use of dynamic contrast enhanced MRI [49]. Arterial spin labeling MRI is a second technique to quantify blood perfusion, but without the use of contrast material. Dai et al. showed increased perfusion activity in BAT after cold stimulation compared with thermoneutral conditions [50]. A third way to depict the blood perfusion of a tissue is a $\mathrm{T}_{2}{ }^{*}$-weighted blood-oxygen-level-dependent MRI (BOLD-MRI). Khanna and Branca used BOLD-MRI for detection of BAT metabolic activity in mice [51], while van Roojen et al. used BOLD-MRI in humans to depict BAT activation during cold stimulation, leading to modulations in the $\mathrm{T}_{2}{ }^{*}$-weighted signal [52]. Branca et al. has finally published multiple studies about the use of hyperpolarized xenon MRI for detection of BAT and thermogenic activity in mice [53].

\section{MRI characteristics of adipose tissue in disease}

Adipose tissue is a key player in various states of metabolic dysfunction. MRI can assess adipose tissue distribution and characterize the tissue without the use of ionizing radiation and without the need of contrast material. This can be of use in risk assessment and monitoring of metabolic dysfunction.

\section{Obesity, Diabetes and Metabolic Syndrome}

The number of patients who suffer from obesity continues to rise [54]. An increased mass of adipose tissue is the primary phenotypic trait in obesity. However, not only the mass, but also a specific distribution of the adipose tissue is associated with the related diseases such as type 2 diabetes and the metabolic syndrome $[55,56]$.

Several studies were able to show that although both the amount of SAT and VAT are correlated with metabolic risk factors, VAT remains more strongly associated with an adverse metabolic risk profile [57 - 59]. This is supposed to be linked to VAT as an endocrine gland. In this context, VAT is an important site for adipokine secretion, for example Interleukin-6, contributing to systemic inflammation [60]. Additionally, the visceral fat mass presumably contributes significantly to the levels of free fatty acids in the systemic circulation [61], which interferes with the insulin balance eventually leading to insulin resistance [62]. 


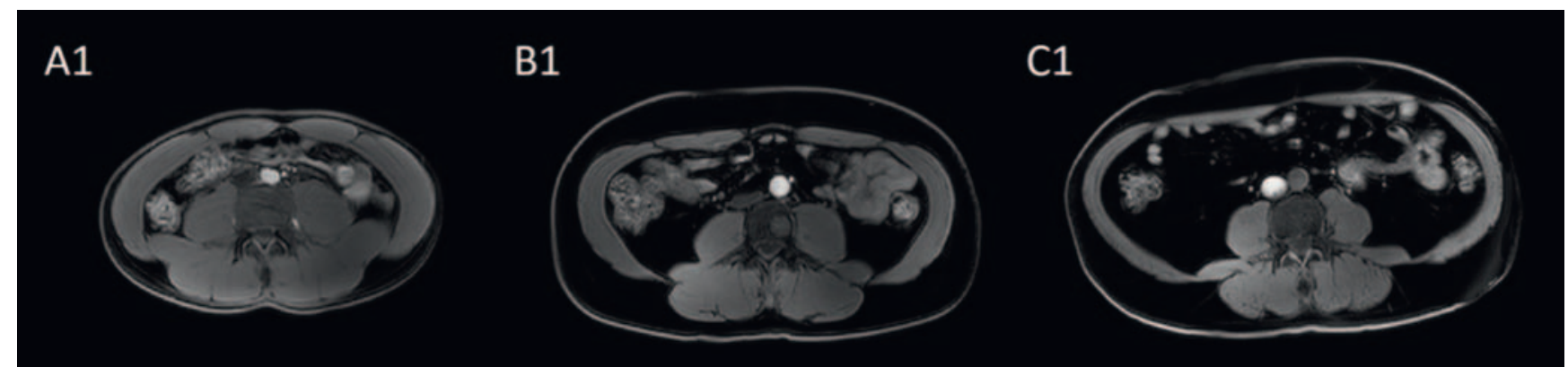

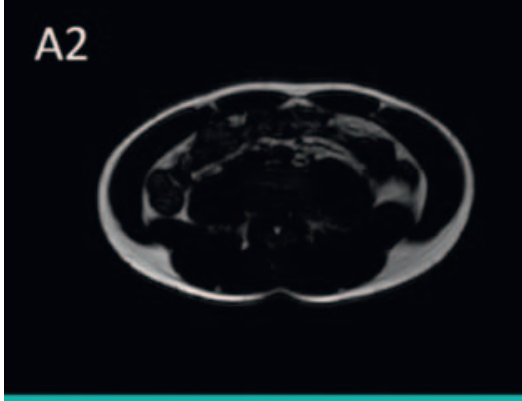

A3

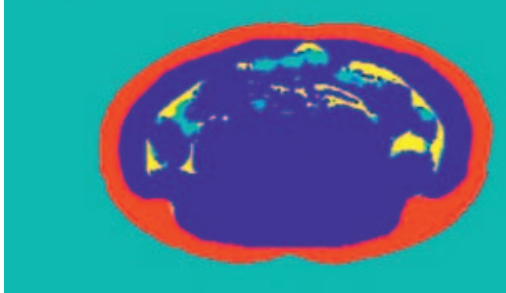

B2

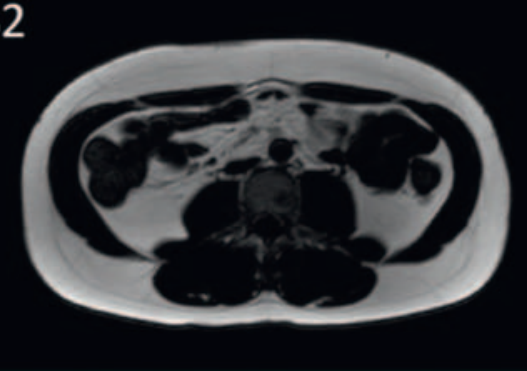

B3

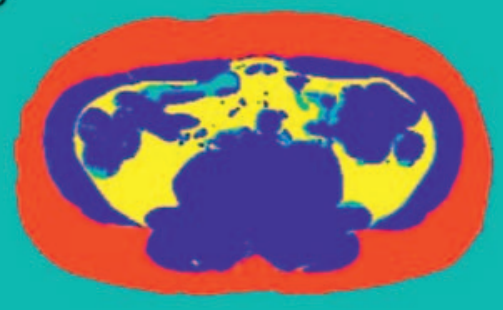

$\mathrm{C} 2$

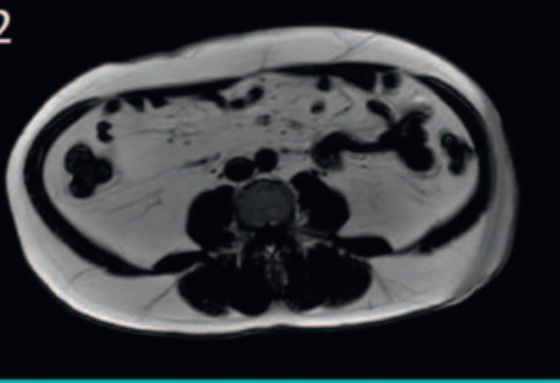

C3

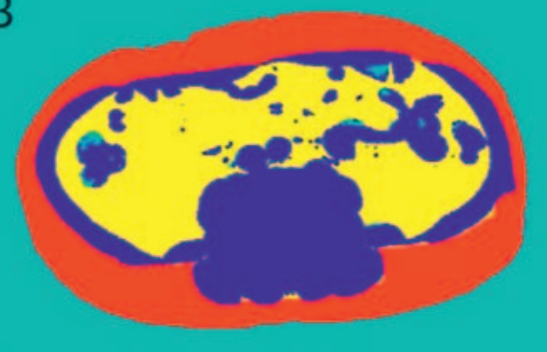

- Fig. 3 Comparison of different fat depots in three male subjects. First row shows water-separated Dixon images, second row shows fat-separated Dixon images and third row shows SAT/VAT segmentation maps (color-coded masking using red for SAT, yellow for VAT, blue for non-adipose tissue and cyan for air). First column A shows a metabolically healthy subject, BMI: $20 \mathrm{~kg} / \mathrm{m}^{2}$. Second column B shows a subject with high BMI but normal insulin sensitivity, BMI: $31 \mathrm{~kg} / \mathrm{m}^{2}$. Third column C shows a pre-diabetic subject, BMI $34 \mathrm{~kg} / \mathrm{m}^{2}$. Note the marked increase of VAT with higher BMI compared to the increase of SAT. BMI: body mass index, SAT: subcutaneous adipose tissue, VAT: visceral adipose tissue.

- Abb. 3 Vergleich verschiedener Fettkompartimente bei drei männlichen Probanden. Die erste Reihe zeigt die Wasser-separierten Dixon-Bilder, die zweite Reihe die Fett-separierten und die dritte Reihe zeigt SAT/VAT Segmentierungs-Karten (farbkodiert, wobei rot SAT entspricht, gelb VAT, blau nicht-fettigem Gewebe und türkis Luft). Die erste Spalte A zeigt einen stoffwechselgesunden Probanden, BMl: $20 \mathrm{~kg} / \mathrm{m}^{2}$. Die zweite Spalte B zeigt einen Probanden mit erhöhtem BMI bei noch normaler Insulinsensitivität, BMI $31 \mathrm{~kg} / \mathrm{m}^{2}$. Die dritte Spalte C zeigt einen prädiabetischen Probanden, BMI $34 \mathrm{~kg} / \mathrm{m}^{2}$. Man beachte die deutliche Zunahme des VAT mit steigendem BMI im Vergleich zum SAT. BMI: Body Mass Index, SAT: subkutanes Fettgewebe, VAT: viszerales Fettgewebe.

MRI adipose tissue segmentation allows the precise differentiation between VAT and SAT ( $\vee$ Fig. $\mathbf{3}, \mathbf{4})$ and thus can contribute to a risk assessment for the development of obesity-related complications $[10,63,64]$. In that regard, Machann et al. found that the fraction of unsaturated fatty acids in VAT was lower in subjects with high total VAT volume [18]. Thomas et al. found the "thin-onthe-outside fat-on-the-inside" subphenotype, with a higher ratio of intraabdominal over subcutaneous abdominal adipose tissue, to have an increased metabolic risk. VAT furthermore seems to be a predictive factor for an improvement of insulin sensitivity in lifestyle interventions [65]. A systematic review on the associations of different adipose tissue depots with insulin resistance, as measured by homeostatic model assessment of insulin resistance (HOMA-IR), found a strong correlation between HOMA-IR and visceral fat mass as well as total fat mass [66].

\section{Anorexia and Cachexia}

Both anorexia (nervosa) and cachexia are characterized by a loss of adipose tissue in addition to skeletal muscle. In the eating disorder anorexia nervosa, MRI can be helpful to determine the amount of adipose tissue in order to identify factors associated with relapse, as relapse rates range from $30 \%$ to $50 \%$ in patients with anorexia nervosa [67]. Bodell et al. showed that lower percent adipose tissue after short-term weight normalization in anorexia nervosa is associated with poor clinical outcome in the year following inpatient treatment [68]. Furthermore, in adult women with anorexia nervosa, Mayer et al. noted that weight normalization in the short term is associated with a distribution of adipose tissue compatible with the central adiposity phenotype, normalizing within a one-year period of weight maintenance [69]. 


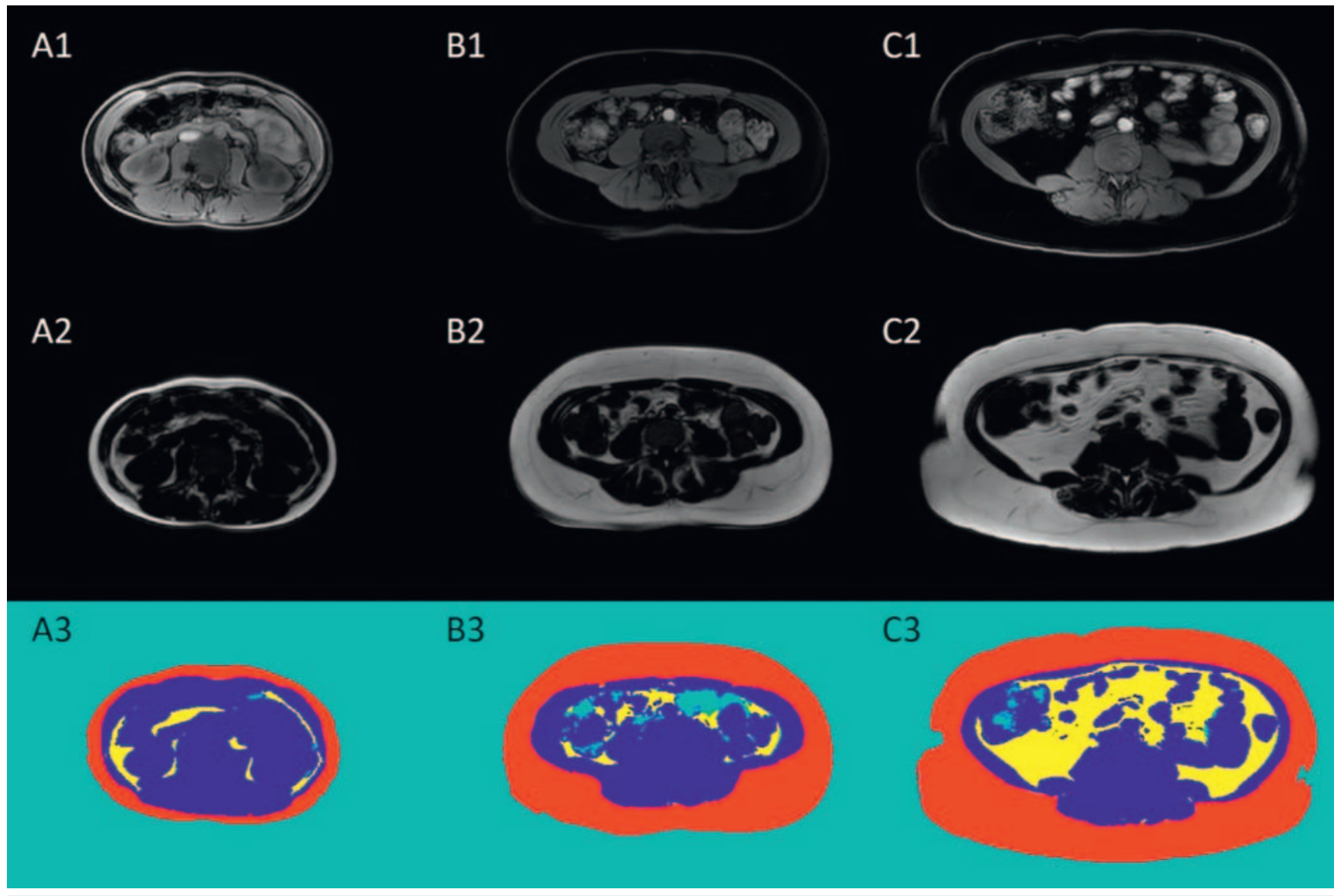

- Fig. 4 Comparison of different fat depots in three female subjects. First row shows water-separated Dixon images, second row shows fat-separated Dixon images and third rows shows SAT/VAT segmentation maps (color-coded masking using red for SAT, yellow for VAT, blue for non-adipose tissue and cyan for air). First column A shows a metabolically healthy subject, BMI: $18 \mathrm{~kg} / \mathrm{m}^{2}$. Second column B shows a subject with high BMI but normal insulin sensitivity, BMl: $31 \mathrm{~kg} / \mathrm{m}^{2}$. Third column C shows a pre-diabetic subject, BMI $35 \mathrm{~kg} / \mathrm{m}^{2}$. Note the marked increase of SAT with higher BMI compared to the increase of VAT. Also note the difference in fat distribution in females in $>$ Fig. 4 compared to males in $>$ Fig. 3 with a considerably higher SAT/VAT ratio in females compared to males. BMI: body mass index, SAT: subcutaneous adipose tissue, VAT: visceral adipose tissue.

- Abb.4 Vergleich verschiedener Fettkompartimente bei drei weiblichen Probandinnen. Die erste Reihe zeigt die Wasser- separierten Dixon-Bilder, die zweite Reihe die Fett-separierten und die dritte Reihe zeigt SAT/VAT Segmentierungs-Karten (farbkodiert, wobei rot SAT entspricht, gelb VAT, blau nicht-fettigem Gewebe und türkis Luft). Die erste Spalte A zeigt eine stoffwechselgesunde Probandin, BMI: $18 \mathrm{~kg} / \mathrm{m}^{2}$. Die zweite Spalte B zeigt eine Probandin mit erhöhtem BMI bei noch normaler Insulinsensitivität, BMI $31 \mathrm{~kg} / \mathrm{m}^{2}$. Die dritte Spalte $\mathbf{C}$ zeigt eine prädiabetische Probandin, BMI $35 \mathrm{~kg} / \mathrm{m}^{2}$. Man beachte die deutliche Zunahme des SAT mit steigendem BMI im Vergleich zur geringeren Zunahme des VAT. Zudem zeigt sich ein gut sichtbarer Unterschied der Fettverteilungsmuster bei Frauen in $\triangleright$ Fig. 4 verglichen mit Männern in $\triangleright$ Fig. 3, wobei die Frauen einen deutlich höheren SAT/VAT Quotienten im Vergleich zu Männern aufweisen. BMI: Body Mass Index, SAT: subkutanes Fettgewebe, VAT: viszerales Fettgewebe.

With regard to the presence of BAT, young women with anorexia nervosa were shown to have low cold-activated BAT, which may be due to impaired BAT thermogenesis [70].

Cachexia, on the other hand, is defined as unintentional body weight loss, mainly due to progressive wasting of skeletal muscle with or without loss of adipose tissue. It occurs in various illnesses, e.g. in cancer, AIDS, inflammatory bowel disease or multiple sclerosis.

In cancer patients, cachexia accounts for up to $30 \%$ of cancer related deaths, attaching importance to a more detailed knowledge about the development and the natural course of cachexia. This renders impact to fat segmentation and quantification tools based on MRI datasets, as the conventional BMI/weight monitor- ing does not account for example for fluid retention or anasarca. Fouladiun et al. monitored the development of cachexia in a cohort of 311 cancer patients and found that decrease in body weight was explained by loss of body fat, preferentially from the trunk, followed by leg tissue and arm tissue [71]. With more precise tools, Agustsson et al. found that WAT was decreased in cachectic compared with normal weight cancer patients, with the cachectic subjects exhibiting a selective decrease in visceral WAT [72]. However, reported data on the use of MRI techniques for monitoring adipose tissue changes in cancer cachexia patients remains up to date limited.

When patients lose muscle mass and muscle function is impaired, this state is called sarcopenia. Sarcopenia can occur in ca- 
chectic patients, but also in patients with abnormally increased BMI (> $\left.30 \mathrm{~kg} / \mathrm{m}^{2}\right)$. The latter state defines sarcopenic obesity. Studies found that cancer patients with coexisting sarcopenic obesity showed poorer survival rates compared to other patients [75].

Regarding BAT in cachexia patients, Petruzzelli et al. found in the mouse model that WAT browning (i.e., a phenotypic switch from WAT to BAT) mediated by systemic inflammation and interleukin-6 contributed to high energy expenditure in cancer-associated cachexia. Inhibition of this process alleviated cachexia in mice [73]. However, data from retrospective studies in cancer patients did not show a clinically relevant association between BAT and cancer cachexia [74].

\section{Conclusion}

The different types of adipose tissues play a crucial role in various types of metabolic dysfunction. Without the use of ionizing radiation and without the need of contrast material, MRI enables characterization of adipose tissue and permits the evaluation of adipose tissue distribution. But not only the current gold standard methods for metabolic phenotyping, namely $T_{1}$ - and $T_{2}$-weighted imaging techniques and MRS, but also new developments in MRI techniques provide researchers with further tools to characterize adipose tissue depots, offering new possibilities for both monitoring and risk stratification purposes with regard to the development and course of metabolic dysfunction.

\section{Conflict of Interest}

Dimitrios C. Karampinos receives grant support from Philips Healthcare.

\section{Acknowledgments}

The present work was supported by the German Research Foundation (DFG-SFB824/A9) and Philips Healthcare.

\section{References}

[1] Kershaw EE, Flier JS. Adipose tissue as an endocrine organ. J Clin Endocrinol Metab 2004; 89: 2548-2556. DOI: 10.1210/jc.2004-0395

[2] Zhou X, Wang JL, Lu J et al. Reversal of cancer cachexia and muscle wasting by ActRIIB antagonism leads to prolonged survival. Cell 2010; 142: 531 - 543. DOI: 10.1016/j.cell.2010.07.011

[3] Mohammad A, De Lucia Rolfe E, Sleigh A et al. Validity of visceral adiposity estimates from DXA against MRI in Kuwaiti men and women. Nutr Diabetes 2017; 7: e238. DOI: 10.1038/nutd.2016.38

[4] Thomas EL, Fitzpatrick JA, Malik S] et al. Whole body fat: content and distribution. Prog Nucl Magn Reson Spectrosc 2013; 73: 56 - 80. DOI: 10.1016/j.pnmrs.2013.04.001

[5] Mitra S, Fernandez-Del-Valle M, Hill JE. The role of MRI in understanding the underlying mechanisms in obesity associated diseases. Biochim Biophys Acta 2017; 1863: 1115-1131. DOI: 10.1016/j.bbadis.2016.09.008

[6] Shen W, Wang Z, Punyanita $M$ et al. Adipose tissue quantification by imaging methods: a proposed classification. Obes Res 2003; 11: 5-16. DOI: $10.1038 /$ oby.2003.3
[7] Baum T, Cordes C, Dieckmeyer M et al. MR-based assessment of body fat distribution and characteristics. Eur J Radiol 2016; 85: 1512 -1518. DOI: 10.1016/j.ejrad.2016.02.013

[8] Yudasaka M, Yomogida Y, Zhang M et al. Near-Infrared Photoluminescent Carbon Nanotubes for Imaging of Brown Fat. Sci Rep 2017; 7: 44760. DOI: $10.1038 /$ srep44760

[9] Sampath SC, Sampath SC, Bredella MA et al. Imaging of Brown Adipose Tissue: State of the Art. Radiology 2016; 280: 4-19. DOI: 10.1148/radiol.2016150390

[10] Cordes C, Dieckmeyer M, Ott B et al. MR-detected changes in liver fat, abdominal fat, and vertebral bone marrow fat after a four-week calorie restriction in obese women. J Magn Reson Imaging 2015; 42: 1272 1280. DOI: $10.1002 / j m r i .24908$

[11] Linder K, Springer F, Machann J et al. Relationships of body composition and liver fat content with insulin resistance in obesity-matched adolescents and adults. Obesity (Silver Spring) 2014; 22: 1325 -1331. DOI: 10.1002/oby. 20685

[12] Machann J, Thamer C, Schnoedt B et al. Standardized assessment of whole body adipose tissue topography by MRI. J Magn Reson Imaging 2005; 21: 455-462. DOI: 10.1002/jmri.20292

[13] Franz D, Karampinos DC, Rummeny E] et al. Discrimination Between Brown and White Adipose Tissue Using a 2-Point Dixon Water-Fat Separation Method in Simultaneous PET/MRI. J Nucl Med 2015; 56: 1742 - 1747. DOI: 10.2967/jnumed.115.160770

[14] Positano V, Gastaldelli A, Sironi AM et al. An accurate and robust method for unsupervised assessment of abdominal fat by MRI. J Magn Reson Imaging 2004; 20: 684-689. DOI: 10.1002/jmri.20167

[15] Gronemeyer SA, Steen RG, Kauffman WM et al. Fast adipose tissue (FAT) assessment by MRI. Magn Reson Imaging 2000; 18: 815-818

[16] $\mathrm{Hu} \mathrm{HH}$, Chen J, Shen W. Segmentation and quantification of adipose tissue by magnetic resonance imaging. MAGMA 2016; 29: 259-276. DOI: 10.1007/s10334-015-0498-z

[17] Kullberg J, Ahlstrom $\mathrm{H}$, Johansson L et al. Automated and reproducible segmentation of visceral and subcutaneous adipose tissue from abdominal MRI. Int J Obes (Lond) 2007; 31: 1806 - 1817. DOI: 10.1038/ sj.ijo.0803671

[18] Machann J, Stefan N, Schabel C et al. Fraction of unsaturated fatty acids in visceral adipose tissue (VAT) is lower in subjects with high total VAT volume - a combined $1 \mathrm{H} \mathrm{MRS}$ and volumetric MRI study in male subjects. NMR Biomed 2013; 26: 232 - 236. DOI: 10.1002/nbm.2849

[19] Thomas EL, Frost G, Barnard ML et al. An in vivo $13 \mathrm{C}$ magnetic resonance spectroscopic study of the relationship between diet and adipose tissue composition. Lipids 1996; 31: 145-51

[20] Beckmann N, Brocard J], Keller U et al. Relationship between the degree of unsaturation of dietary fatty acids and adipose tissue fatty acids assessed by natural-abundance $13 \mathrm{C}$ magnetic resonance spectroscopy in man. Magn Reson Med 1992; 27: 97-106

[21] Tucci S, Flogel U, Sturm M et al. Disrupted fat distribution and composition due to medium-chain triglycerides in mice with a beta-oxidation defect. Am J Clin Nutr 2011; 94: 439-449. DOI: 10.3945/ ajcn.111.012948

[22] Reeder SB, Hu HH, Sirlin CB. Proton density fat-fraction: a standardized MR-based biomarker of tissue fat concentration. J Magn Reson Imaging 2012; 36: 1011 -1014. DOI: 10.1002/jmri.23741

[23] Bannas $\mathrm{P}$, Kramer $\mathrm{H}$, Hernando $\mathrm{D}$ et al. Quantitative magnetic resonance imaging of hepatic steatosis: Validation in ex vivo human livers. Hepatology 2015; 62: 1444 -1455. DOI: 10.1002/hep.28012

[24] Tang A, Tan J, Sun M et al. Nonalcoholic fatty liver disease: MR imaging of liver proton density fat fraction to assess hepatic steatosis. Radiology 2013; 267: 422 -431. DOI: 10.1148/radiol.12120896

[25] Yokoo T, Serai SD, Pirasteh A et al. Linearity, Bias, and Precision of Hepatic Proton Density Fat Fraction Measurements by Using MR Ima- 
ging: A Meta-Analysis. Radiology 2018; 286: 486-498. DOI: 10.1148| radiol. 2017170550

[26] Franz D, Weidlich D, Freitag F et al. Association of proton density fat fraction in adipose tissue with imaging-based and anthropometric obesity markers in adults. Int J Obes (Lond) 2017. doi:10.1038/ijo.2017.194

[27] $\mathrm{Hu} \mathrm{HH}$, Hines CD, Smith DL et al. Variations in $\mathrm{T}(2)^{*}$ and fat content of murine brown and white adipose tissues by chemical-shift MRI. Magn Reson Imaging 2012; 30: 323 -329. DOI: 10.1016/j.mri.2011.12.004

[28] Rosen ED, Spiegelman BM. What we talk about when we talk about fat. Cell 2014; 156: 20 -44. DOI: 10.1016/j.cell.2013.12.012

[29] Golan R, Shelef I, Rudich A et al. Abdominal superficial subcutaneous fat: a putative distinct protective fat subdepot in type 2 diabetes. Diabetes Care 2012; 35: 640 -647. DOI: 10.2337/dc11-1583

[30] Shen J, Baum T, Cordes C et al. Automatic segmentation of abdominal organs and adipose tissue compartments in water-fat MRI: Application to weight-loss in obesity. Eur J Radiol 2016; 85: 1613-1621. DOI: 10.1016/j.ejrad.2016.06.006

[31] Garnov N, Linder N, Schaudinn A et al. Comparison of T1 relaxation times in adipose tissue of severely obese patients and healthy lean subjects measured by 1.5 T MRI. NMR Biomed 2014; 27: 1123-1128. DOI: $10.1002 / n b m .3166$

[32] Hu HH, Tovar JP, Pavlova Z et al. Unequivocal identification of brown adipose tissue in a human infant. J Magn Reson Imaging 2012; 35: 938 942. DOI: 10.1002/jmri.23531

[33] Franssens BT, Eikendal AL, Leiner T et al. Reliability and agreement of adipose tissue fat fraction measurements with water-fat MRI in patients with manifest cardiovascular disease. NMR Biomed 2016; 29: 48 - 56. DOI: $10.1002 / \mathrm{nbm} .3444$

[34] Franssens BT, Hoogduin H, Leiner T et al. Relation between brown adipose tissue and measures of obesity and metabolic dysfunction in patients with cardiovascular disease. J Magn Reson Imaging 2017; 46: 497 - 504. DOI: $10.1002 /$ jmri.25594

[35] Sadananthan SA, Khoo EYH, Leow M, Khoo C, Venkataraman K, Lee YS, Chong YS, Gluckman PD, Tai ES, Velan, S. S., editor. Effect of Weight Loss and Regional Differences in Abdominal Adipose Tissue Hydration; International Society for Magnetic Resonance in Medicine: Toronto, Canada., 2015

[36] Hamilton G, Schlein AN, Middleton MS et al. In vivo triglyceride composition of abdominal adipose tissue measured by $1 \mathrm{H}$ MRS at 3T. J Magn Reson Imaging 2017; 45: 1455 - 1463. DOI: 10.1002/jmri.25453

[37] Machann J, Stefan N, Wagner R et al. Intra- and interindividual variability of fatty acid unsaturation in six different human adipose tissue compartments assessed by $1 \mathrm{H}-\mathrm{MRS}$ in vivo at $3 \mathrm{~T}$. NMR Biomed 2017; 30: doi:10.1002/nbm.3744

[38] Cypess AM, Lehman S, Williams G et al. Identification and importance of brown adipose tissue in adult humans. N Engl J Med 2009; 360: 1509 1517. DOI: 10.1056/NEJMoa0810780

[39] Harms M, Seale P. Brown and beige fat: development, function and therapeutic potential. Nat Med 2013; 19: 1252-1263. DOI: $10.1038 /$ nm.3361

[40] Cannon B, Nedergaard J. Brown adipose tissue: function and physiological significance. Physiol Rev 2004; 84: 277 -359. DOI: 10.1152 | physrev.00015.2003

[41] Heaton JM. The distribution of brown adipose tissue in the human. J Anat 1972; 112: $35-9$

[42] van Marken Lichtenbelt WD, Vanhommerig JW, Smulders NM et al. Coldactivated brown adipose tissue in healthy men. N Engl J Med 2009; 360: 1500 - 1508. DOI: 10.1056/NEJMoa0808718

[43] Kim H, Pennisi PA, Gavrilova O et al. Effect of adipocyte beta3-adrenergic receptor activation on the type 2 diabetic MKR mice. Am J Physiol Endocrinol Metab 2006; 290: E1227 -E1236. DOI: 10.1152/ajpendo.00344.2005
[44] Hu HH, Yin L, Aggabao PC et al. Comparison of brown and white adipose tissues in infants and children with chemical-shift-encoded water-fat MRI. J Magn Reson Imaging 2013; 38: 885 - 896. DOI: 10.1002/ jmri.24053

[45] Rasmussen JM, Entringer S, Nguyen A et al. Brown adipose tissue quantification in human neonates using water-fat separated MRI. PLoS One 2013; 8: e77907. DOI: 10.1371/journal.pone.0077907

[46] Hamilton G, Smith DL, Bydder M Jr et al. MR properties of brown and white adipose tissues. J Magn Reson Imaging 2011; 34: 468 - 473. DOI: 10.1002/jmri.22623

[47] Lau AZ, Chen AP, Gu Y et al. Noninvasive identification and assessment of functional brown adipose tissue in rodents using hyperpolarized (1)(3)C imaging. Int J Obes (Lond) 2014; 38: 126-131. DOI: 10.1038/ ijo.2013.58

[48] Grimpo K, Volker MN, Heppe EN et al. Brown adipose tissue dynamics in wild-type and UCP1-knockout mice: in vivo insights with magnetic resonance. J Lipid Res 2014; 55: 398 -409. DOI: 10.1194/jlr.M042895

[49] Sbarbati A, Cavallini I, Marzola P et al. Contrast-enhanced MRI of brown adipose tissue after pharmacological stimulation. Magn Reson Med 2006; 55: 715 - 718. DOI: 10.1002/mrm.20851

[50] Dai W, Weiner LS, Alsop DC. Feasibility and repeatability of brown adipose tissue volume and perfusion activity using MRI. Proceedings of 23 rd Int Society for Magnetic Resonance in Medicine. 2015: 539

[51] Khanna A, Branca RT. Detecting brown adipose tissue activity with BOLD MRI in mice. Magn Reson Med 2012; 68: 1285 - 1290. DOI: 10.1002/ mrm. 24118

[52] van Rooijen BD, van der Lans AA, Brans B et al. Imaging cold-activated brown adipose tissue using dynamic $\mathrm{T} 2{ }^{*}$-weighted magnetic resonance imaging and 2-deoxy-2-[18F]fluoro-D-glucose positron emission tomography. Invest Radiol 2013; 48: 708-714. DOI: 10.1097/RLI.0b013e31829363b8

[53] Branca RT, He T, Zhang L et al. Detection of brown adipose tissue and thermogenic activity in mice by hyperpolarized xenon MRI. Proc Natl Acad Sci U S A 2014; 111: 18001 -18006. DOI: 10.1073/ pnas. 1403697111

[54] Flegal KM, Kruszon-Moran D, Carroll MD et al. Trends in Obesity Among Adults in the United States, 2005 to 2014. JAMA 2016; 315: 2284 2291. DOI: $10.1001 /$ jama.2016.6458

[55] Fujioka S, Matsuzawa Y, Tokunaga K et al. Contribution of intra-abdominal fat accumulation to the impairment of glucose and lipid metabolism in human obesity. Metabolism 1987; 36: $54-59$

[56] Goodpaster BH, Thaete FL, Simoneau JA et al. Subcutaneous abdominal fat and thigh muscle composition predict insulin sensitivity independently of visceral fat. Diabetes 1997; 46: 1579-1585

[57] Fox CS, Massaro JM, Hoffmann U et al. Abdominal visceral and subcutaneous adipose tissue compartments: association with metabolic risk factors in the Framingham Heart Study. Circulation 2007; 116: 39-48. DOI: 10.1161/CIRCULATIONAHA.106.675355

[58] Anderson PJ, Chan JC, Chan YL et al. Visceral fat and cardiovascular risk factors in Chinese NIDDM patients. Diabetes Care 1997; 20: 1854 - 1858

[59] Despres JP, Lamarche B. Effects of diet and physical activity on adiposity and body fat distribution: implications for the prevention of cardiovascular disease. Nutr Res Rev 1993; 6: 137-159. DOI: 10.1079/ NRR19930010

[60] Fontana L, Eagon JC, Trujillo ME et al. Visceral fat adipokine secretion is associated with systemic inflammation in obese humans. Diabetes 2007; 56: 1010 -1013. DOI: 10.2337/db06-1656

[61] Bjorntorp P. Metabolic implications of body fat distribution. Diabetes Care 1991; 14: $1132-1143$

[62] Wajchenberg BL. Subcutaneous and visceral adipose tissue: their relation to the metabolic syndrome. Endocr Rev 2000; 21: $697-738$. DOI: 10.1210/edrv.21.6.0415 
[63] Machann J, Thamer C, Schnoedt B et al. Age and gender related effects on adipose tissue compartments of subjects with increased risk for type 2 diabetes: a whole body MRI/MRS study. MAGMA 2005; 18: 128-137. DOI: $10.1007 / s 10334-005-0104-x$

[64] Thomas EL, Parkinson JR, Frost GS et al. The missing risk: MRI and MRS phenotyping of abdominal adiposity and ectopic fat. Obesity (Silver Spring) 2012; 20: 76 - 87. DOI: 10.1038/oby.2011.142

[65] Machann J, Thamer C, Stefan N et al. Follow-up whole-body assessment of adipose tissue compartments during a lifestyle intervention in a large cohort at increased risk for type 2 diabetes. Radiology 2010; 257: 353 363. DOI: 10.1148/radiol.10092284

[66] Zhang M, Hu T, Zhang S et al. Associations of Different Adipose Tissue Depots with Insulin Resistance: A Systematic Review and Meta-analysis of Observational Studies. Sci Rep 2015; 5: 18495. DOI: 10.1038/ srep 18495

[67] Pike KM. Long-term course of anorexia nervosa: response, relapse, remission, and recovery. Clin Psychol Rev 1998; 18: 447-475

[68] Bodell LP, Mayer LE. Percent body fat is a risk factor for relapse in anorexia nervosa: a replication study. Int J Eat Disord 2011; 44: 118-123. DOI: 10.1002/eat.20801

[69] Mayer LE, Klein DA, Black E et al. Adipose tissue distribution after weight restoration and weight maintenance in women with anorexia nervosa. Am J Clin Nutr 2009; 90: 1132 -1137. DOI: 10.3945/ajcn.2009.27820
[70] Bredella MA, Fazeli PK, Freedman LM et al. Young women with coldactivated brown adipose tissue have higher bone mineral density and lower Pref-1 than women without brown adipose tissue: a study in women with anorexia nervosa, women recovered from anorexia nervosa, and normal-weight women. J Clin Endocrinol Metab 2012; 97: E584 E590. DOI: 10.1210/jc.2011-2246

[71] Fouladiun M, Korner U, Bosaeus I et al. Body composition and time course changes in regional distribution of fat and lean tissue in unselected cancer patients on palliative care-correlations with food intake, metabolism, exercise capacity, and hormones. Cancer 2005; 103 : 2189-2198. DOI: 10.1002/cncr.21013

[72] Agustsson T, Wikrantz P, Ryden M et al. Adipose tissue volume is decreased in recently diagnosed cancer patients with cachexia. Nutrition 2012; 28: 851 - 855. DOI: 10.1016/j.nut.2011.11.026

[73] Petruzzelli M, Schweiger M, Schreiber R et al. A switch from white to brown fat increases energy expenditure in cancer-associated cachexia. Cell Metab 2014; 20: 433-447. DOI: 10.1016/j.cmet.2014.06.011

[74] Beijer E, Schoenmakers J, Vijgen G et al. A role of active brown adipose tissue in cancer cachexia? Oncol Rev 2012; 6: e11. DOI: 10.4081/oncol.2012.e11

[75] Carneiro IP, Mazurak VC, Prado CM. Clinical Implications of Sarcopenic Obesity in Cancer. Curr Oncol Rep 2016; 18: 62. DOI: 10.1007/s11912016-0546-5 